\title{
Xp11.22 duplications in four unrelated Chinese families: delineating the genotype- phenotype relationship for HSD17B10 and FGD1
}

Qingming Wang ${ }^{1,2}$, Pengliang Chen ${ }^{1}$, Jianxin Liu' ${ }^{1}$, Jiwu Lou ${ }^{1,2}$, Yanhui Liu ${ }^{1,2^{*}}$ and Haiming Yuan ${ }^{1,2^{*}}$

\begin{abstract}
Background: Xp11.22 duplications have been reported to contribute to nonsyndromic intellectual disability (ID). The HUWE1 gene has been identified in all male Xp11.22 duplication patients and is associated with nonsyndromic ID. Currently, few Xp11.22 duplication cases have been reported in the Chinese population, with limited knowledge regarding the role of other genes in this interval.

Case presentation: We investigated four unrelated Chinese male Xp11.22 duplication patients, performed a comprehensive clinical evaluation for the patients and discussed the role of other genes in this interval. All patients presented with similar clinical features, including ID, speech impairments and motor delay, which were mostly consistent with those of the Xp11.22 duplication described previously. We searched and compared all cases and noted that one of the probands (Family 1) and DECIPHER case 263,219, who carried small overlapping duplications at Xp11.22 that only covered the entire HSD17B10 gene, also suffered from ID, suggesting the important role of HSD17B10 in this interval. Furthermore, three patients (two probands in Families 3 and 4 and DECIPHER case 249, 490) had strikingly similar hypogonadism phenotypes, including micropenis, small testes and cryptorchidism, which have not been previously described in Xp11.22 duplication patients. Interestingly, the FGD1 gene was duplicated only in these three patients. Sufficient evidence has suggested that haploinsufficiency of the FGD1 gene causes Aarskog-Scott syndrome, which is characterized by hypogonadism and other abnormalities. Given that, we are the first group to propose that $F G D 1$ may be a potential dosage-sensitive gene responsible for the hypogonadism observed in our patients.
\end{abstract}

Conclusion: We reported novel genotypes and phenotypes in Chinese male Xp11.22 duplication patients, and the HSD17B10 and FGD1 genes may be involved.

Keywords: Xp11.22 duplication, Intellectual disability, HUWE1, HSD17B10, FGD1

\section{Background}

Xp11.23p11.22 duplication is a recurrent copy number variant $(\mathrm{CNV})$ mediated by the non-allelic homologous

\footnotetext{
* Correspondence: yh523120@sina.com; haimingyuan@sina.cn 'Dongguan Maternal and Child Health Care Hospital, Dongguan 523120, China

Full list of author information is available at the end of the article
}

recombination (NAHR) between flanking low copy repeats (LCRs), which is a gene-rich region implicated in neurodevelopmental abnormalities, including ID, severe language delay, autistic behaviors, epilepsy and early onset of puberty [1-6]. Within this region, the nonrecurrent duplication at Xp11.22 has inconsistent breakpoints and is a relatively gene-poor region associated with

(c) The Author(s). 2020 Open Access This article is licensed under a Creative Commons Attribution 4.0 International License, which permits use, sharing, adaptation, distribution and reproduction in any medium or format, as long as you give appropriate credit to the original author(s) and the source, provide a link to the Creative Commons licence, and indicate if changes were made. The images or other third party material in this article are included in the article's Creative Commons licence, unless indicated otherwise in a credit line to the material. If material is not included in the article's Creative Commons licence and your intended use is not permitted by statutory regulation or exceeds the permitted use, you will need to obtain permission directly from the copyright holder. To view a copy of this licence, visit http://creativecommons.org/licenses/by/4.0/ The Creative Commons Public Domain Dedication waiver (http://creativecommons.org/publicdomain/zero/1.0/) applies to the data made available in this article, unless otherwise stated in a credit line to the data. 
nonsyndromic ID. To date, 18 unrelated families with overlapping duplications at Xp11.22 have been described, and most patients share similar clinical features, including ID, delayed motor development and delayed language [6-10]. Comparing these duplicated segments, the HUWE1 gene, coding the E3 ubiquitin protein ligase, turned out to be duplicated in all previously described patients. Therefore, an increased dosage of HUWE1 is believed to be responsible for nonsyndromic ID [6-10]. To date, little is known about the clinical consequences of other genes involved in this interval, and the genotype-phenotype relationship is still limited. Here, we present four additional, unrelated Chinese families with male patients suffering from mild to moderate ID and developmental delay, all of whom harbor overlapping duplications at Xp11.22. The proband (Family 1) and DECIPHER case 263,219 have ID and carry small Xp11.22 duplications partially encompassing HUWE1, suggesting the involvement of other ID genes in this interval. It is also interesting that two of our probands (Families 3 and 4) and DECIPHER case 249,490 show a similar hypogonadism phenotype that has not been described in previously reported patients with Xp11.22 duplication. In this study, we further explored the genotype-phenotype associations and the potential genes involved in the process.

\section{Case presentation \\ Family 1}

The proband was the first male child of a nonconsanguineous couple. His 2-year-old younger brother was unaffected. His only maternal uncle had ID and speech impairments (Fig. 1). The proband was born at 38 weeks of gestation with a weight, height, and head circumference well within the normal ranges. His weight was $11.5 \mathrm{~kg}(32 \%)$, height $86 \mathrm{~cm}(44.6 \%)$, and head circumference $48 \mathrm{~cm}(46 \%)$ on physical examination at 1 year 10 months because of developmental delay. He had no language development and suffered from cognitive impairments. Motor development was significantly delayed: he raised his head at 8 months, sat alone at 1 year and could not independently stand.

On last physical examination at the age of 4 years, growth parameters were normal, and no dysmorphic facial features were recognized. He presented with remarkable absence of speech and mild ID with an intelligence quotient of 70 by the Wechsler Preschool and Primary Scale of Intelligence (WPPSI-III). He could walk

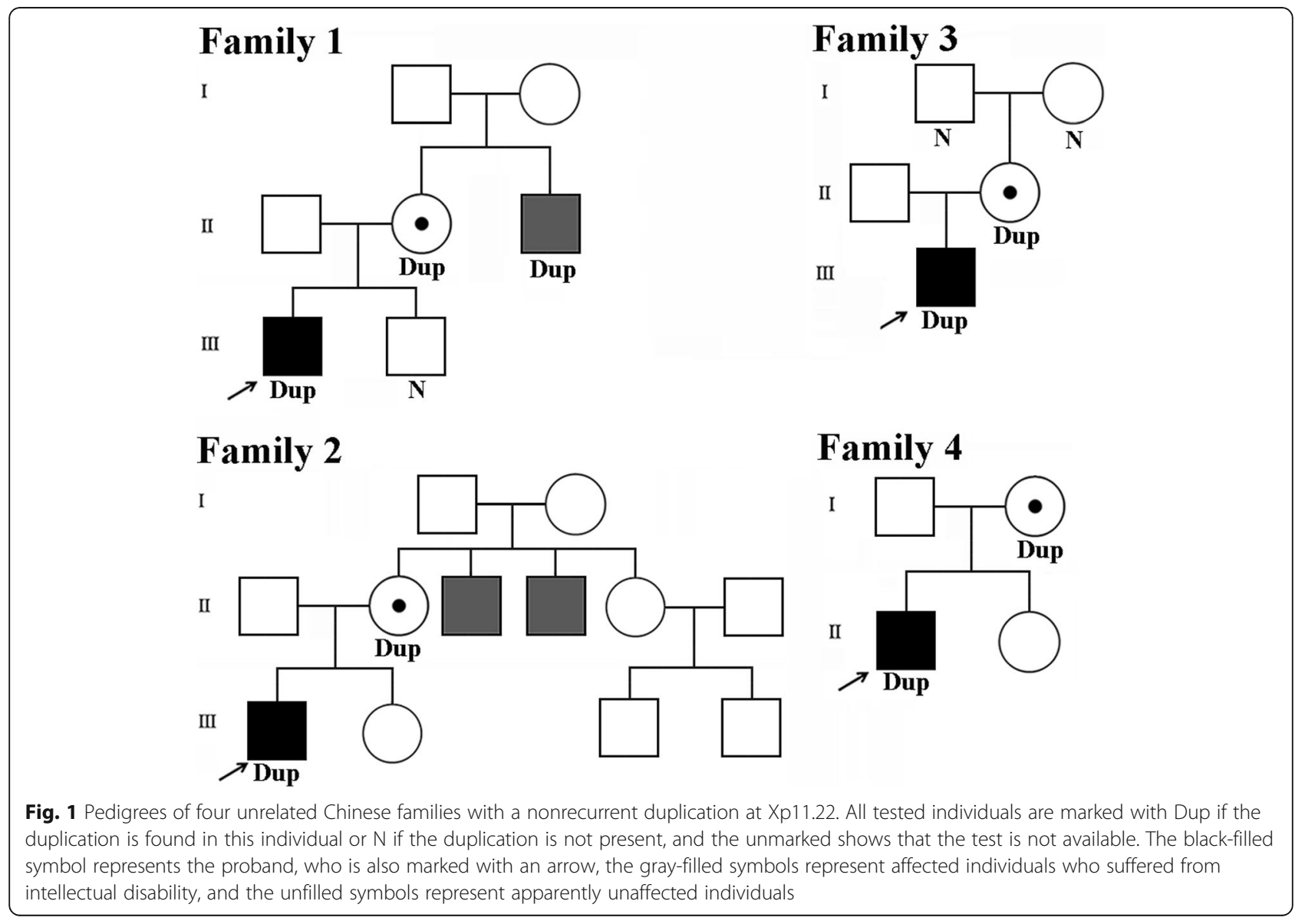


independently, but his gait was unstable, and he fell frequently. Brain magnetic resonance imaging was normal.

\section{Family 2}

The male proband was the second child of healthy, unrelated parents. The family history was obviously remarkable. His elderly sister was healthy. Both maternal uncles suffered from ID and limited speech. The unaffected maternal aunt had two healthy sons (Fig. 1). The proband's mother was treated with progesterone during pregnancy due to signs of spontaneous abortion. The boy was born at 38 weeks gestational age by spontaneous vaginal delivery. The birth weight was $3 \mathrm{~kg}$ (20.3\%) and length $50 \mathrm{~cm}$ (40.9\%). No feeding problems were noted after birth. At the age of 9 months, he was referred to the clinic due to developmental delay.

Molecular genetic testing was performed for the boy at the age of 4 years and 4 months. His growth development was within the normal range: weight $17 \mathrm{~kg}(43.1 \%)$, height $106 \mathrm{~cm}$ (45.7\%), and head circumference $50.5 \mathrm{~cm}$ (49.9\%). He had delayed motor development: he raised his head at 5 months, sat alone at 10 months and walked without assistance at 1.5 years. His language development was remarkably delayed with only two-word formed sentences. He presented with mild ID and attention deficit hyperactivity disorder (ADHD).

At age 7, normal growth development and the absence of distinctive facial features were confirmed. He was diagnosed with mild ID (Intelligence Quotient $=70$ ) and poor language abilities but had learned to read and write. Brain magnetic resonance imaging was normal. No other abnormalities were observed.

\section{Family 3}

This boy was the only son of healthy, nonconsanguineous parents. There was no family history of ID or other genetic disorders. The maternal siblings were apparently healthy (Fig. 1). The mother underwent an uneventful pregnancy that ended in a spontaneous vaginal delivery at 38 weeks of gestation. He had normal birth measurements: weight $3.2 \mathrm{~kg}$ (38.2\%), length $51 \mathrm{~cm}$ $(63.3 \%)$ and head circumference $34.5 \mathrm{~cm}$ (50\%). No feeding difficulties were noted after birth.

His height was $94 \mathrm{~cm}$ (57.3\%), weight $13.0 \mathrm{~kg}$ (32.9\%) and head circumference $49 \mathrm{~cm}(46.7 \%)$ at the age of 2.5 years. Motor development was delayed: he raised his head at 6 months, sat alone at 1 year and walked independently at 2 years. He had no language development. In addition to speech delay, he showed poor motor coordination with abnormal gait and mild ID. No distinctive facial features were observed. Hypogonadism was noted, including micropenis, small testes and cryptorchidism. At 4 years 9 months, a general examination showed a height of $109 \mathrm{~cm}$ (46.1\%), a weight of $17.8 \mathrm{~kg}$
(40.2\%) and a head circumference of $50.5 \mathrm{~cm}$ (40.9\%), indicating normal growth development. Cognitive evaluation was performed and demonstrated mild ID (Intelligence Quotient $=65$ ). His language skills were still poor, and he only formed two-word sentences. Brain magnetic resonance imaging and electroencephalography were normal.

\section{Family 4}

The patient, a 13-year-old boy, was second-born to a nonconsanguineous couple and had a healthy female sibling (Fig. 1). He was born at 37 weeks gestational age by spontaneous vaginal delivery. Birth measurements were within the normal range. Language development was significantly delayed, and he began to talk at 4 years and had simple reading skills at 11 years. He suffered from moderate ID with hypogonadism, including micropenis and small testes. He was noted to have delays in motor development: he raised his head at 7 months, sat alone at 1 year and walked at 3 years. His growth development was normal. No significant dysmorphic facial features were noted. Brain magnetic resonance imaging revealed brain dysplasia. No other abnormalities were observed.

\section{Whole exome sequencing (WES) and chromosomal microarray analysis (CMA)}

A total 10,231 individuals with neurodevelopmental disorders were recruited to Dongguan Maternal and Child Health Care Hospital for genetic testing during 20102019. This study was approved by the Committee on Ethics of the Dongguan Maternal and Child Health Care Hospital. DNA of family members was extracted from peripheral blood lymphocytes using standard methods. The patients' peripheral blood DNA was subjected to whole exome sequencing (Illumina) to screen for causal variants. The bcl2fastq2 Conversion Software (v2.20) was applied for extracting Fastq files. BWA (v0.2.10) was employed for genome alignments and variant detection. The ExomeDepth (v1.1.4) was used for CNVs analysis. Clinic Sequence Analyzer (CSA) software was used for biological analysis and interpretation. The pathogenicity of the sequence variants was interpreted in accordance with the American College of Medical Genetics and Genomics/Association for Molecular Pathology (ACMG/AMP) guidelines [11]. Chromosomal microarray analysis (CMA) was performed using the CytoS$\operatorname{can}^{\mathrm{Tm}}$ HD array (Thermo Fisher). Chromosome Analysis Suite (ChAS) was applied for analysis of the raw data. The interpretation of the CNVs was performed according to the American College of Medical Genetics (ACMG) guidelines [12]. 


\section{Whole genome sequencing (WGS)}

Whole genome sequencing (Illumina) was employed for the proband (Family 1) to determine the structural rearrangements and precise breakpoints of the small duplicated segment. WGS was operated with an Illumina HiSeq 2500 system (Illumina) with $150 \mathrm{bp}$ pair-end reads. The target coverage was $30 \mathrm{X}$, and two sequencing libraries with target insert sizes of approximately 300$400 \mathrm{bp}$ were constructed and sequenced in four lanes. Agilent 2100 bioanalyzer (Agilent Technologies) was used to evaluate the quality of the sequencing libraries.

In all families, WES tests revealed no clinically significant sequence variants associated with the probands' clinical features but implicated duplications in the Xp11.22 region. Next, CMA tests were used to confirm and refine the Xp11.22 duplications.

In Family 1, a $292 \mathrm{~kb}$ duplication at Xp11.22 was detected in the proband, the mother and the affected maternal uncle. The genomic coordinates were chrX:53, 355,898-53,647,498 (GRCh37/hg19), encompassing the entirety of the HSD17B10 and SMC1A genes, as well as part of HUWE1 (Fig. 2). The proband's healthy younger brother did not inherit the duplication from the mother. The WGS test showed that the small duplication was $287 \mathrm{~kb}$ with precise genomic coordinates chrX:53,358, 265-53,645,732 (GRCh37/hg19) spanning the full HSD17B10 and SMC1A genes, as well as part of $H U W E 1$, and verified that the duplication was in tandem orientation. Apparently, HUWE1 was partially duplicated, which suggested one functional copy of the gene (Fig. 3).

In Family 2, a $564 \mathrm{~kb}$ duplication at Xp11.22 was identified in the proband. The genomic coordinates were 53, 428,070-53,992,238 (GRCh37/hg19) (Fig. 2). The unaffected mother was the carrier of the duplication, which was most likely an inherited event because of the remarkable family history of most males suffering from ID and speech impairments.

In Family 3, a $1.9 \mathrm{Mb}$ duplication was detected at Xp11.22 with genomic coordinates 52,686,671-54,621, 465 (GRCh37/hg19) in the proband (Fig. 2). The unaffected mother carried the duplication, which was a de novo event, because the duplication was absent in the maternal grandmother and grandfather.

In Family 4, a $2.6 \mathrm{Mb}$ duplication at Xp11.22 was revealed with genomic coordinates 52,923,471-55,551,584 (GRCh37/hg19) in the proband, which was inherited from the unaffected mother (Fig. 2).

\section{Discussion and conclusions}

Nonrecurrent Xp11.22 duplications have been reported to be relevant to nonsyndromic ID. At present, patients with overlapping duplications at Xp11.22 have been described in 18 unrelated families. Comparing all male patients with the Xp11.22 duplication, we found that the commonly shared characteristics were the presence of a mild-to-moderate ID and language delay [6-10]. A common minimal overlapping region was identified that contained only the HUWE1 gene. Therefore, it was concluded that HUWE1 was likely to be a dosage-sensitive gene and that an increased dosage of HUWE1 was believed to be responsible for nonsyndromic ID $[7,8]$. To date, little is known about the clinical consequences of other genes involved in this interval. Here, we presented an additional four unrelated Chinese families with Xp11.22 duplications. All male patients demonstrated similar clinical features, including ID, speech impairments and motor delay, as the most consistent features of individuals with Xp11.22 duplication. To further establish the genotype-phenotype correlations, we searched and compared all Xp11.22 duplication cases as shown in Table 1 and Fig. 4.

We observed that the proband (Family 1) and DECIPHER patient 263,219, who carried a small duplication at Xp11.22 partially overlapping HUWE1 also presented with ID and language delay. The partial HUWE1 copy number gain would probably not contribute to ID, as demonstrated in families with the partial HUWE1 duplication previously reported, since segregation analysis provided contradictory evidence [8]. The partial HUWE1 duplication is also reported in the Database of Genomic Variants (esv3576879). In Family 1, the duplicated segment entirely encompassed the HSD17B10 and $S M C 1 A$ genes. The boy suffered from ID, speech impairments and motor delay. This duplication was inherited from the unaffected mother. The proband's duplication-negative younger brother had a normal development, and the duplication-carrying maternal uncle showed a similar clinical presentation to that of the proband. The cosegregation evidence from this family implied that the small duplication at Xp11.22 was a disease-causing effect. Next, the WGS test was used to analyze the structural rearrangements of the duplication. The small duplication was confirmed to be in tandem orientation, and HUWE1 was partially duplicated, which suggested one functional copy of the gene [Fig. 3]. Furthermore, the WGS test also confirmed that there were no other known genetic causes responsible for the clinical features of the proband. It was found that DECIPHER case 263,219, who carried a de novo small duplication at Xp11.22, entirely spanning HSD17B10 but only partially $H U W E 1$ and $S M C 1 A$, displayed speech impairments and global developmental delay. The de novo event implicated that the small duplication was clinically significant. Based on current evidence, it is reasonable to conclude that this small duplication is likely to be causally linked with the patients' phenotype. The overlapping region of the two patients only fully covered the 

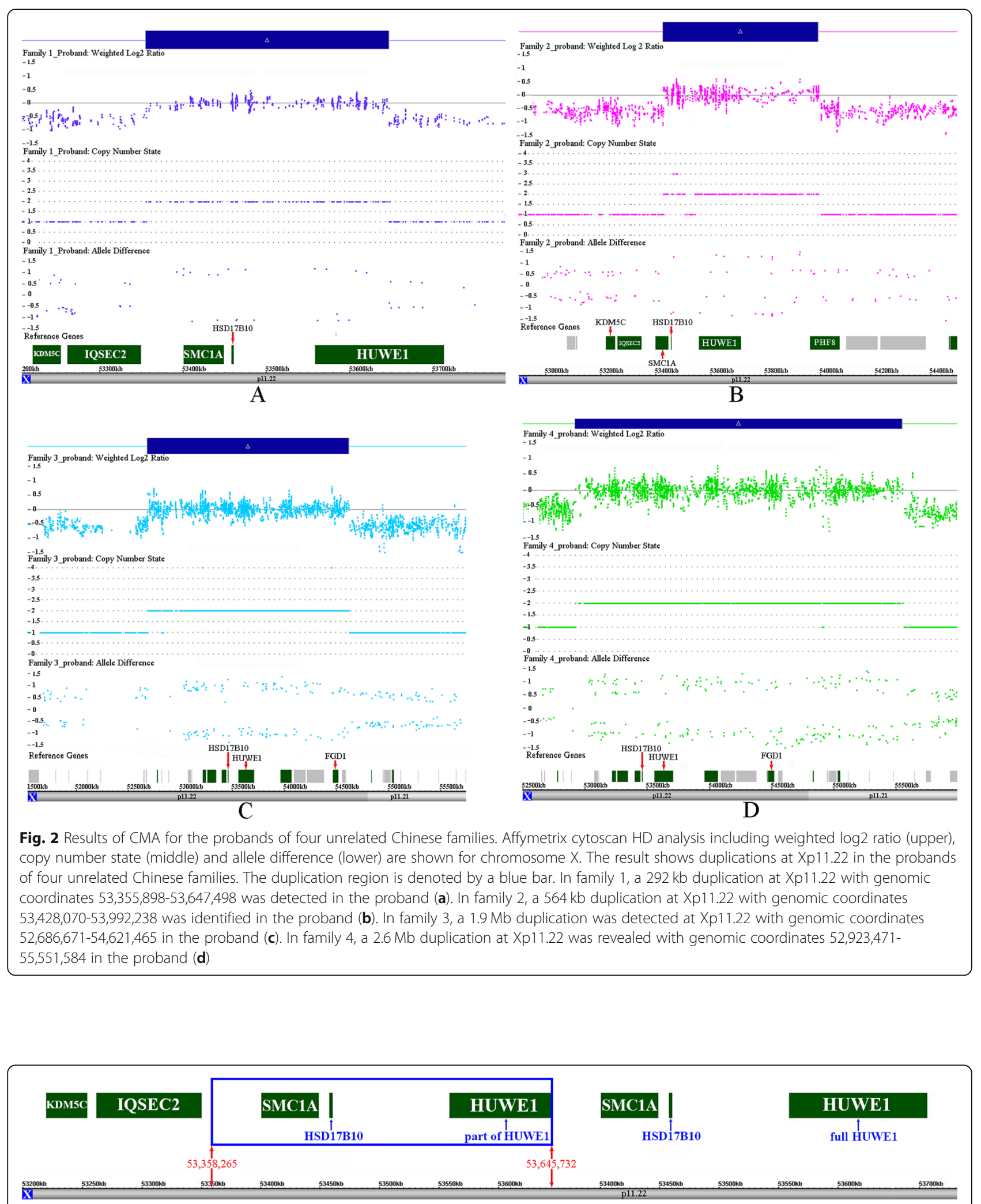

Fig. 3 Structural rearrangement of the Xp11.22 microduplication in the proband (Family 1). WGS shows that the small duplication (Family 1) is $287 \mathrm{~kb}$ with precise genomic coordinates chrX:53,358,265-53,645,732 (GRCh37/hg19) spanning the entirety of the HSD17B10 and SMC1A genes, as well as part of HUWE1, and reveals that the duplication was in tandem orientation. The duplication region is surrounded by a blue box. Obviously, HUWE1 is partially duplicated, which suggests one functional copy of the gene 
Table 1 Clinical features observed in patients with duplications at Xp11.22. The genomic coordinates are based on GRCH37/hg19

\begin{tabular}{|c|c|c|c|c|c|c|c|c|c|}
\hline Reference & $\begin{array}{l}\text { Genomic } \\
\text { location (chrX) }\end{array}$ & Size & Origin & $\begin{array}{l}\text { ID } \\
\text { Growth }\end{array}$ & $\begin{array}{l}\text { Growth } \\
\text { delay }\end{array}$ & $\begin{array}{l}\text { Motor } \\
\text { delay }\end{array}$ & $\begin{array}{l}\text { Language } \\
\text { delay }\end{array}$ & $\begin{array}{l}\text { Facial } \\
\text { dysmorphism }\end{array}$ & Other phenotypes \\
\hline Our family 1 & $\begin{array}{l}53,358,265-53 \\
645,732\end{array}$ & $\begin{array}{l}287 \\
\mathrm{~kb}\end{array}$ & mat & + & - & + & + & - & \\
\hline Our family 2 & $\begin{array}{l}53,428,070-53 \\
992,238\end{array}$ & $\begin{array}{l}564 \\
\mathrm{~kb}\end{array}$ & mat & + & - & + & + & - & $\mathrm{ADHD}$ \\
\hline Our family 3 & $\begin{array}{l}52,686,671-54 \\
621,465\end{array}$ & $\begin{array}{l}1.9 \\
\mathrm{Mb}\end{array}$ & mat & + & - & + & + & - & $\begin{array}{l}\text { micropenis, small testes, } \\
\text { cryptorchidism }\end{array}$ \\
\hline Our family 4 & $\begin{array}{l}52,923,471-55 \\
551,584\end{array}$ & $\begin{array}{l}2.6 \\
\mathrm{Mb}\end{array}$ & mat & + & - & + & + & - & micropenis, small testes \\
\hline DECIPHER 263219 & $\begin{array}{l}53,449,334-53 \\
681,188\end{array}$ & $\begin{array}{l}232 \\
\mathrm{~kb}\end{array}$ & de novo & + & + & + & + & + & \\
\hline DECIPHER 249490 & $\begin{array}{l}51,786,514-55 \\
633,505\end{array}$ & $\begin{array}{l}3.9 \\
\mathrm{Mb}\end{array}$ & unknown & NR & NR & NR & + & + & micropenis, small testes \\
\hline Froyen et al. (2008) FAM3 [7] & $\begin{array}{l}53,384,357-53 \\
723,273\end{array}$ & $\begin{array}{l}339 \\
\mathrm{~kb}\end{array}$ & mat & + & - & NR & + & + & $\mathrm{ADHD}$ \\
\hline Froyen et al. (2008) P083 [7] & $\begin{array}{l}53,440,734-53 \\
852,372\end{array}$ & $\begin{array}{l}412 \\
k b\end{array}$ & unknown & + & - & NR & + & - & \\
\hline Froyen et al. (2008) A057 [7] & $\begin{array}{l}52,987,653-53 \\
713,244\end{array}$ & $\begin{array}{l}726 \\
\mathrm{~kb}\end{array}$ & unknown & + & - & - & + & - & $\mathrm{ADHD}$ \\
\hline Froyen et al. (2008) A009 [7] & $\begin{array}{l}53,220,275-53 \\
981,275\end{array}$ & $\begin{array}{l}761 \\
\mathrm{~kb}\end{array}$ & mat & + & - & NR & NR & NR & \\
\hline Froyen et al. (2008) A049 [7] & $\begin{array}{l}53,392,906-53 \\
770,862\end{array}$ & $\begin{array}{l}378 \\
\mathrm{~kb}\end{array}$ & mat & + & - & NR & NR & NR & \\
\hline Froyen et al. (2008) A119 [7] & $\begin{array}{l}52,823,215-53 \\
664,301\end{array}$ & $\begin{array}{l}841 \\
\mathrm{~kb}\end{array}$ & unknown & + & - & + & + & - & ADHD, seizure \\
\hline Froyen et al. (2012) EX469 [8] & $\begin{array}{l}53,484,936-53 \\
957,276\end{array}$ & $\begin{array}{l}472 \\
\mathrm{~kb}\end{array}$ & mat & + & NR & NR & + & + & seizure \\
\hline Froyen et al. (2012) F538 [8] & $\begin{array}{l}53,216,303-54 \\
239,670\end{array}$ & $\begin{array}{l}1.0 \\
\mathrm{Mb}\end{array}$ & mat & + & NR & NR & + & + & \\
\hline $\begin{array}{l}\text { Froyen et al. (2012) AU88848 } \\
\text { [8] }\end{array}$ & $\begin{array}{l}53,169,907-54 \\
101,252\end{array}$ & $\begin{array}{l}931 \\
\mathrm{~kb}\end{array}$ & mat & + & NR & NR & NR & NR & \\
\hline Froyen et al. (2012) FTD [8] & $\begin{array}{l}53,198,995-54 \\
237,527\end{array}$ & $\begin{array}{l}1.0 \\
\mathrm{Mb}\end{array}$ & mat & + & - & + & + & + & ADHD, cryptorchidism \\
\hline Froyen et al. (2012) SB1 [8] & $\begin{array}{l}53,370,418-53 \\
790,660\end{array}$ & $\begin{array}{l}420 \\
\mathrm{~Kb}\end{array}$ & mat & + & - & + & + & + & \\
\hline Froyen et al. (2012) ON1 [8] & $\begin{array}{l}52,977,428-53 \\
963,113\end{array}$ & $\begin{array}{l}986 \\
\mathrm{~Kb}\end{array}$ & mat & + & - & + & + & + & $\mathrm{ADHD}$ \\
\hline $\begin{array}{l}\text { Orivoli et al. (2016) Patient } \\
\text { [10] }\end{array}$ & $\begin{array}{l}53,459,179-53 \\
822,042\end{array}$ & $\begin{array}{l}363 \\
k b\end{array}$ & de novo & + & + & + & + & + & \\
\hline $\begin{array}{l}\text { Santos-Rebouças et al. (2015) } \\
\text { Patient } 611 \text { [9] }\end{array}$ & $\begin{array}{l}53,316,256-54 \\
074,258\end{array}$ & $\begin{array}{l}758 \\
k b\end{array}$ & mat & + & - & - & + & + & $\mathrm{ADHD}$ \\
\hline $\begin{array}{l}\text { Santos-Rebouças et al. (2015) } \\
\text { Patient } 3272 \text { [9] }\end{array}$ & $\begin{array}{l}53,228,169-54 \\
133,735\end{array}$ & $\begin{array}{l}905 \\
\mathrm{~kb}\end{array}$ & mat & + & - & + & + & + & ADHD, seizure \\
\hline $\begin{array}{l}\text { Grams et al. (2016) Patient } 1 \\
\text { [6] }\end{array}$ & $\begin{array}{l}53,160,114-53 \\
713,154\end{array}$ & $\begin{array}{l}897 \\
\mathrm{~kb}\end{array}$ & mat & + & - & + & + & + & $\mathrm{ADHD}$ \\
\hline $\begin{array}{l}\text { Grams et al. (2016) Patient } 7 \\
\text { [6] }\end{array}$ & $\begin{array}{l}53,198,565-53 \\
969,809\end{array}$ & $\begin{array}{l}771 \\
\mathrm{~kb}\end{array}$ & mat & + & + & + & + & + & $\mathrm{ADHD}$ \\
\hline $\begin{array}{l}\text { Grams et al. (2016) Patient } 11 \\
\text { [6] }\end{array}$ & $\begin{array}{l}53,548,808-54 \\
062,110\end{array}$ & $\begin{array}{l}513 \\
\mathrm{~kb}\end{array}$ & mat & + & + & + & + & + & \\
\hline
\end{tabular}

ID Intellectual disability, ADHD Attention deficit hyperactivity disorder, NR Not reported.

$H S D 17 B 10$ gene. Therefore, $H S D 17 B 10$ was regarded as the most promising gene responsible for the patient's phenotype. The HSD17B10 gene encodes human $17 \beta$ - hydroxysteroid dehydrogenase type 10 (17ß-HSD10), a mitochondrial multifunctional enzyme that catalyzes the oxidation of neuroactive steroids and the degradation of 


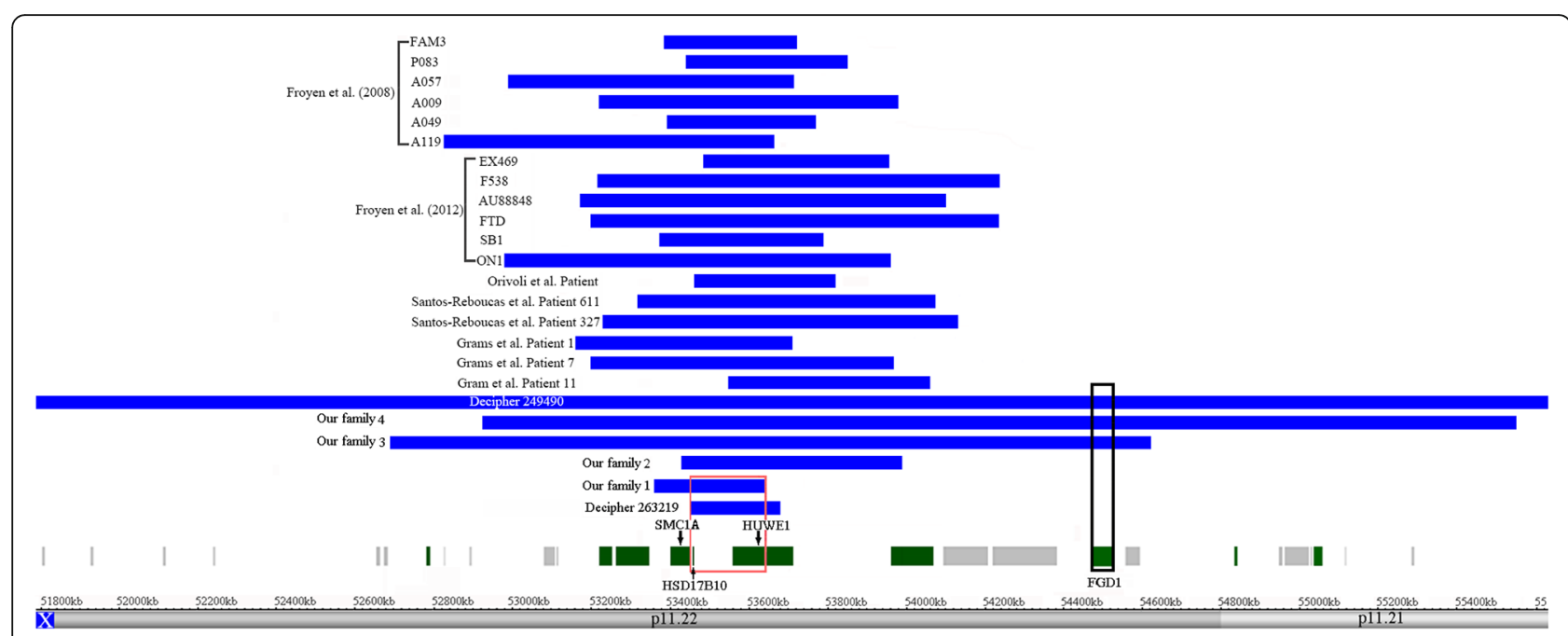

Fig. 4 A genome view of all Xp11.22 duplication cases. The panel shows a genome view of all Xp11.22 duplication cases (blue colored custom tracks) extracted from Human Genome Build 37 (hg19). The minimal overlapping region of one of our probands (Family 1 ) and DECIPHER 263219 only spans the entire HSD17B10 gene, which is surrounded by a red box. The FGD1 gene is duplicated exclusively in two of our probands (Families 3 and 4) and DECIPHER 249490, which is surrounded by a black box

isoleucine. The enzyme can bind to various peptides and is required for normal mitochondrial maintenance [13]. $17 \beta$-HSD10 is expressed in brain tissue at different levels and is most abundant in the hippocampus [14]. Normal levels of $17 \beta$-HSD10 in various brain regions and other tissues are essential for human health, particularly normal cognitive competence $[13,15]$. Mutations in the HSD17B10 gene lead to $17 \beta$-HSD10 deficiency, a progressive neurodegenerative disorder with age at onset ranging from the neonatal period to early childhood, characterized by ID, deficits in language, motor delay, and alteration of mitochondrial morphology [16]. In addition, elevated 17 $\beta$-HSD10 levels have been found in the hippocampi of Alzheimer's patients and in a mouse model $[14,17,18]$. It is therefore likely that not only a reduced activity but also an increased dosage of HSD10 might interfere with normal cognition through the disturbed metabolism of neurosteroid modulators of $\mathrm{GABA}_{\mathrm{A}}$ receptors $[13,18]$. Based on the clinical and functional evidence for $H S D 17 B 10$ duplication, we propose that $H S D 17 B 10$ may be a dosage-sensitive gene and that $H S D 17 B 10$ duplication is likely to be causally linked with the patients' phenotypes.

Interestingly, two of our other probands (Families 3 and 4) and DECIPHER patient 249,490 all presented with strikingly similar hypogonadism phenotypes, including micropenis, small testes and cryptorchidism, which have not been reported in any of the previously described Xp11.22 duplication patients. The FGD1 gene was duplicated exclusively in the three patients. Currently, sufficient evidence has suggested that mutations or deletions in the FGD1 gene cause Aarskog-Scott syndrome (AAS), also known as facio-digito-genital dysplasia, characterized by hypogonadism and other abnormalities with a broad spectrum of clinical phenotypes [19-22]. In this study, WES tests excluded the sequence variants of the FGD1 gene and other known genetic factors associated with hypogonadism in the probands (Families 3 and 4). To date, little is known about the clinical significance of $F G D 1$ gene duplication (the triplosensitivity score for the $F G D 1$ gene is zero based on the ClinGen gene dosage sensitivity scoring protocol). Given that the FGD1 gene was duplicated exclusively in the three unrelated patients who all displayed strikingly similar hypogonadism phenotypes and that other Xp11.22 duplication patients did not show this feature, it is reasonable to speculate that FGD1 is likely to be a dosage-sensitive gene and that FGD1 duplication may be responsible for hypogonadism observed in our patients.

It has been known that deletions and reciprocal duplications encompassing a dosage-sensitive gene could lead to clinical phenotypes that can be broadly classified into four general categories: mirrored (opposite effects), identical, overlapping, and unique [23]. For example, haploinsufficiency of $M E C P 2$ causes Rett syndrome, a severe neurodevelopmental disorder [24]. Duplications encompassing the entire $M E C P 2$ gene are responsible for MECP2 duplication syndrome, leading to similar phenotypes characterized by intellectual disability, global developmental delay, autistic behavior, epilepsy and recurrent infections [25]. Haploinsufficiency of NSD1 results in Sotos syndrome, recognized by pre-postnatal generalized overgrowth with advanced bone age, intellectual disability, and a typical facial appearance [26], whereas reciprocal duplications covering the entire NSD1 gene display reverse clinical features, including 
delayed bone age, microcephaly and failure to thrive [27]. Recently, more dosage-sensitive genes have gradually been revealed, although the present evidence is not sufficient but is accumulating; these genes, including ZEB2 [28] and AHDC1 [29], deserve further study. Here, we provide the first evidence suggesting that $H S D 17 B 10$ and FGD1 may be such dosage-sensitive genes.

We reported on four unrelated Chinese families with individuals who carried duplications at the Xp11.22 interval, and cosegregation evidence in the four pedigrees further implicated nonrecurrent Xp11.22 duplication in nonsyndromic ID. By comparing the genotypephenotype relationships of all patients with Xp11.22 duplications, HSD17B10 and FGD1 were identified as potential dosage-sensitive genes responsible for the clinical presentations observed in our patients. Additional clinical cases and functional studies are needed to prove this hypothesis.

\section{Abbreviations}

ID: Intellectual disability; FGD1: Faciogenital dysplasia 1; AAS: Aarskog-Scott syndrome; CNVs: Copy number variants; NAHR: Non-allelic homologous recombination; LCRs: Low copy repeats; ADHD: Attention deficit hyperactivity disorder; WES: Whole exome sequencing; CMA: Chromosomal microarray analysis; WGS: Whole Genome Sequencing; ACMG/AMP: American College of Medical Genetics and Genomics/Association for Molecular Pathology

\section{Acknowledgments}

We would like to thank the families involved for their cooperation with this study.

\section{Authors' contributions}

Q.M.W. drafted the first versions of the manuscript. Y.H.L. and H.M.Y. were responsible for the design of the project, data analysis, and manuscript writeup. P.L.C., J.X.L. and J.W.L. assisted in the literature review and performed the experiments, data entry, and data analysis phases of the project. All authors read and approved the final manuscript.

\section{Funding}

This study was supported by the Dongguan Social Development Project (No.201950715007158 to Yanhui Liu). The funding body participated in the design of the project and interpretation of whole exome sequencing and chromosomal microarray data.

\section{Availability of data and materials}

The data used and/or analyzed in the present report was deposited in the NCBI BioProject database. The data is accessible via the accession number: PRJNA627852; or via the links: https://www.ncbi.nlm.nih.gov/bioproject/ PRJNA627852.

\section{Ethics approval and consent to participate}

Written informed consent to participate in the genetic testing and this study was obtained from the patients' families, including the patients, the patient's mothers, the patient's uncle in Family 1, and the maternal grandparents in Family 3. This study was approved by the Committee on Ethics of the Dongguan Maternal and Child Health Care Hospital and was performed in accordance with the Declaration of Helsinki.

\section{Consent for publication}

Written informed consent for publication of clinical and genetic data was obtained from all participants. The parents /legal guardian of the children (under the age of 18) has signed written informed consent for publication of clinical and genetic data.

\section{Competing interests}

The authors declare that they have no competing interests.

\section{Author details}

'Dongguan Maternal and Child Health Care Hospital, Dongguan 523120,

China. 'Dongguan Institute of Reproductive and Genetic Research,

Dongguan 523120, China.

Received: 1 August 2019 Accepted: 30 April 2020

Published online: 07 May 2020

\section{References}

1. Bonnet C, Grégoire MJ, Brochet K, Raffo E, Leheup B, Jonveaux P. Pure denovo $5 \mathrm{Mb}$ duplication at Xp11.22-p11.23 in a male: phenotypic and molecular characterization. J Hum Genet. 2006;51(9):815-21.

2. Giorda R, Bonaqlia MC, Beri S, Fichera M, Novara F, Maqini P, et al. Complex segmental duplications mediate a recurrent dup $(X)(p 11.22-p 11.23)$ associated with mental retardation, speech delay, and EEG anomalies in males and females. Am J Hum Genet. 2009;85(3):394-400.

3. Edens AC, Lyons MJ, Duron RM, Dupont BR, Holden KR. Autism in two females with duplications involving Xp11.22-p11.23. DevMed Child Neurol. 2011;53(5):463-6.

4. Flynn M, Zou YS, Milunsky A. Whole gene duplication of the PQBP1 gene in syndrome resembling Renpenning. Am J Med Genet A. 2011;155A(1):141-4.

5. Nizon M, Andrieux J, Rooryck C, de Blois MC, Bourel-Ponchel E, Bourgois B, et al. Phenotype-genotype correlations in 17 new patients with an Xp11. 23p11.22 microduplication and review of the literature. Am J Med Genet A. 2015;167A(1):111-22.

6. Grams SE, Argiropoulos B, Lines M, Chakraborty P, Mcgowan-Jordan J, Geraghty MT, et al. Genotype-phenotype characterization in 13 individuals with chromosome Xp11.22 duplications. Am J Med Genet A. 2016;170A(4): 967-77.

7. Froyen G, Corbett M, Vandewalle J, Jarvela I, Lawrence O, Meldrum C, et al. Submicroscopic duplications of the hydroxysteroid dehydrogenase HSD17B10 and the E3 ubiquitin ligase HUWE1 are associated with mental retardation. Am J Hum Genet. 2008;82(2):432-43.

8. Froyen G, Belet S, Martinez F, Santos-Reboucas CB, Declercq M, Verbeeck J, et al. Copy-number gains of HUWE1 due to replication- and recombinationbased rearrangements. Am J Hum Genet. 2012;91(2):252-64.

9. Santos-Reboucas CB, de Almeida LG, Belet S, Dos Santos SR, Ribeiro MG, da Silva AF, et al. Novel microduplications at Xp11.22 including HUWE1: clinical and molecular insights into these genomic rearrangements associated with intellectual disability. J Hum Genet. 2015;60(4):207-11.

10. Orivoli S, Pavlidis E, Cantalupo G, Pezzella M, Zara F, Garavelli L, et al. Xp11. 22 microduplications including HUWE1: case report and literature review. Neutopediatrics. 2016;47(1):51-6.

11. Richards S, Aziz N, Bale S, Bick D, Das S, Gastier-Foster J, et al. Standards and guidelines for the interpretation of sequence variants: a joint consensus recommendation of the American College of Medical Genetics and Genomics and the Association for Molecular Pathology. Genet Med. 2015; 17(5):405-24.

12. Kearney HM, Thorland EC, Brown KK, Quintero-Rivera F, South ST. Working Group of the American College of medical genetics laboratory quality assurance committee. American College of Medical Genetics standards and guidelines for interpretation and reporting of postnatal constitutional copy number variants. Genet Med. 2011;13(7):680-5.

13. Yang SY, He XY, Miller D. HSD17B10: a gene involved in cognitive function through metabolism of isoleucine and neuroactive steroids. Mol Genet Metab. 2007:92(1-2):36-42.

14. He XY, Weqiel J, Yang SY. Intracellular oxidation of allopregnanolone by human brain type 10 17beta-hydroxysteroid dehydrogenase. Brain Res. 2005;1040(1-2):29-35.

15. Yang SY, He XY, Miller D. Hydroxysteroid (17 $\beta$ ) dehydrogenase $X$ in human health and disease. Mol Cell Endocrinol. 2011;343(1-2):1-6.

16. Zschocke J. HSD10 disease: clinical consequences of mutations in the HSD17B10 gene. J Inherit Metab Dis. 2012;35(1):81-9.

17. He XY, Wen GY, Merz G, Lin D, Yang YZ, Mehta P, Schulz H, Yang SY. Abundant type 1017 beta-hydroxysteroid dehydrogenase in the hippocampus of mouse Alzheimer's disease model. Brain Res Mol Brain Res. 2002;99(1):46-53.

18. He XY, Dobkin C, Yang SY. 17ß-Hydroxysteroid dehydrogenases and neurosteroid metabolism in the central nervous system. Mol Cell Endocrinol. 2019;489:92-7. 
19. Orrico A, Galli L, Obregon MG, de Castro Perez MF, Falciani M, Sorrentino V. Unusually severe expression of craniofacial features in Aarskog-Scott syndrome due to a novel truncating mutation of the FGD1 gene. Am J Med Genet A. 2007:143A(1):58-63.

20. Orrico A, Galli L, Faivre L, Clayton-Smith J, Azzarello-Burri SM, Hertz JM, et al. Aarskog-Scott syndrome: clinical update and report of nine novel mutations of the FGD1 gene. Am J Med Genet A. 2010;152A(2):313-8.

21. Bedoyan JK, Friez MJ, DuPont B, Ahmad A. First case of deletion of the faciogenital dysplasia 1 (FGD1) gene in a patient with Aarskog-Scott syndrome. Eur J Med Genet. 2009;52(4):262-4.

22. Ge Y, Li N, Wang Z, Wang J, Cai H. Novel variant in the FGD1 gene causing Aarskog-Scott syndrome. Exp Ther Med. 2017;13(6):2623-8.

23. Golzio C, Katsanis N. Genetic architecture of reciprocal CNVs. Curr Opin Genet Dev. 2013;23(3):240-8.

24. Amir RE, Van den Vewer IB, Wan M, Tran CQ, Francke U, Zoghbi HY. Rett syndrome is caused by mutations in X-linked MECP2, encoding methylCpG-binding protein 2. Nat Genet. 1999;23(2):185-8.

25. Van Esch H. MECP2 duplication syndrome. GeneReviews ${ }^{\circledR}$ [internet]. Seattle: University of Washington, Seattle; 1993. 2019.

26. Tatton-Brown K, Cole TRP, Rahman N, Syndrome S. GeneReviews ${ }^{\circledR}$. Seattle: University of Washington, Seattle; 2004. 1993-2015.

27. Novara F, Stanzial F, Rossi E, Benedicenti F, Inzana F, Di Gregorio E, et al. Defining the phenotype associated with microduplication reciprocal to Sotos syndrome microdeletion. Am J Med Genet A. 2014;164A(8):2084-90.

28. Wang Q, Huang X, Liu Y, Peng Q, Zhang Y, Liu J, Yuan H. Microdeletion and microduplication of $1 \mathrm{p} 36.11 \mathrm{p} 35.3$ involving AHDC1 contribute to neurodevelopmental disorder. Eur J Med Genet. 2019;\$1769-7212(18): 30411-7.

29. Yuan H, Zhang L, Chen M, Zhu J, Meng Z, Liang L. A de novo triplication on 2 q22.3 including the entire ZEB2 gene associated with global developmental delay, multiple congenital anomalies and behavioral abnormalities. Mol Cytogenet. 2015;8:99.

\section{Publisher's Note}

Springer Nature remains neutral with regard to jurisdictional claims in published maps and institutional affiliations.

Ready to submit your research? Choose BMC and benefit from:

- fast, convenient online submission

- thorough peer review by experienced researchers in your field

- rapid publication on acceptance

- support for research data, including large and complex data types

- gold Open Access which fosters wider collaboration and increased citations

- maximum visibility for your research: over $100 \mathrm{M}$ website views per year

At $\mathrm{BMC}$, research is always in progress.

Learn more biomedcentral.com/submissions 